\title{
Morphometric and Structural Properties of a Sustainable Plant Biomass with Water Purification Potentials
}

\author{
Adeyemi O. Adeeyo ${ }^{1, *(\mathbb{D}}$, John O. Odiyo ${ }^{2,3}{ }^{\text {, Abimbola M. Enitan }}{ }^{4}$, Machawe M. Motsa ${ }^{5}$ (D) Titus A.M. Msagati ${ }^{5}$, \\ Hosana D. Mkoyi ${ }^{6}$ and Rachel Makungo ${ }^{2}$ (D)
}

1 Department of Ecology and Resource Management, Faculty of Science, Engineering and Agriculture, UNIVEN, Thohoyandou 0950, South Africa

2 Department of Hydrology and Water Resource, School of Environmental Sciences, UNIVEN, Thohoyandou 0950, South Africa; johno@vut.ac.za (J.O.O.); rachel.makungo@univen.ac.za (R.M.)

3 Office of The DVC-Research Innovation Commercialisation and Internationalisation (RICI), Vaal University of Technology, Vanderbijlpark 1911, South Africa

4 Department of Biotechnology and Food Technology, Durban University of Technology, Durban 4000, South Africa; enitanabimbola@gmail.com

5 Institute for Nanotechnology and Water Sustainability, UNISA Science Campus, Florida 1710, South Africa; motsamm@unisa.ac.za (M.M.M.); msagatam@unisa.ac.za (T.A.M.M.)

6 Department of Life and Consumer Sciences, College of Agriculture and Environmental Sciences, UNISA Science Campus, Florida 1710, South Africa; mkoyihd@unisa.ac.za

check for updates

Citation: Adeeyo, A.O.; Odiyo, J.O.; Enitan, A.M.; Motsa, M.M.; Msagati, T.A.; Mkoyi, H.D.; Makungo, R. Morphometric and Structural Properties of a Sustainable Plant Biomass with Water Purification Potentials. Sustainability 2021, 13, 11075. https://doi.org/10.3390/ su131911075

Academic Editors: Guillermo Cristian Guadalupe Martínez Ávila, Olga Miriam Rutiaga-Quiñones and Romeo Rojas

Received: 23 July 2021

Accepted: 25 September 2021

Published: 7 October 2021

Publisher's Note: MDPI stays neutral with regard to jurisdictional claims in published maps and institutional affiliations.

Copyright: (c) 2021 by the authors. Licensee MDPI, Basel, Switzerland. This article is an open access article distributed under the terms and conditions of the Creative Commons Attribution (CC BY) license (https:// creativecommons.org/licenses/by/ $4.0 /)$.
* Correspondence: firstrebby@gmail.com; Tel.: +27-723030995

\begin{abstract}
The leaf, stem, and root of wild sesame with eco-physiological functions of water and mineral sorption were targeted for water treatment. Morphometric properties of the plant sections were investigated by light microscopy. Structural and surface characteristics of pulverized samples were studied by thermogravimetry (TGA), Raman spectroscopy, Brunauer-Emmett-Teller (BET), and Scanning electron microscopy. Wettability and sorption potentials were studied by sessile drop analysis, while a methylene blue dye polluted water treated with the plant's sorbents was assessed by UV-Vis spectroscopy. The presence of parenchyma cells, trichomes, vessels, fibres, cellulose, lignin, and other pore-containing structures was confirmed. The stem and root biomasses possessed comparatively higher pore sizes ( 0.011 and $0.124 \mu \mathrm{m}$, respectively), surface energy (33.32 and $31.8 \mathrm{mN} / \mathrm{m})$, and dispersive components $(32.45$ and $31.65 \mathrm{mN} / \mathrm{m})$. The leaf was high in polar components and had a biomass surface area of $3.19 \mathrm{~m}^{2} / \mathrm{g}$. Water treated with the root and stem sorbents gave the lowest dye concentration $(0.19 \mathrm{mg} / \mathrm{L}$ and $0.20 \mathrm{mg} / \mathrm{L}$, respectively) in treated effluent at 120 mins. It was noted that eco-physiological properties informed water purification potentials of the sampled biomasses and could be used for bioprospecting of useful plant materials for water purification. This study established that functional components of plants, porous characteristics, and surface properties of the materials studied are important factors when considering plant sorbents for water purification.
\end{abstract}

Keywords: morphometric; plant biomass; water purification

\section{Introduction}

Successful application of different biomaterials as sorbents for the purification of water have been reported. Biomaterials have been used for the treatment of different water contaminants such as dyes, heavy metals, microbes, biopharmaceutical waste, and other emerging water contaminants. Different structural compositions such as fibre, pith, lignin, polysaccharides, pectin, and cellulose have been reported in plants used for water purification [1,2]. It has been reported that eco-physiological and anatomical structures in plants may account for different adaptations and functions. Foreknowledge of the properties and characteristics of biomaterials aiding adsorption would result in appropriate selection of sorbents with improved water purification processes [3]. This also enhances 
green innovation in the field of water treatment and quality improvement [4]. Structural properties may also play an important role in determining adsorption rate [5-7].

In recent years, a considerable number of studies have focused on low-cost alternative materials for water treatment from agricultural materials [8]. Several agro-industrial wastes and residues have been investigated for adsorption with varying success. These include coconut shell [9], cassava peel, walnut shell, coffee bean husk, corn cob, rice husk, pecan shell and sugar cane bagasse [10], Pyracantha coccinea [11], rice husk [12,13], Thuja orientalis biomass [14], lignocellulose-biomass, jute fiber [15], and Quercus ilex L. biomass [16]. These biomasses have been used as adsorbents for the removal of different contaminants from polluted water. However, new economical, easily available, and highly effective adsorbents are still needed [8]. Of particular interest is the emergence of a wild Sesame in South Africa for water purification. This plant appears to be a suitable candidate for commercial exploitation. Its antibacterial properties have been established and can be explored for water treatment [17-23]. It is considered a multipurpose plant resource used ethnomedicinally for consumption and as a cleaning aid [22]. The use of its mucilaginous leaves as an eco-friendly and cheap adsorbent for removal of $\mathrm{Pb}$ (II) ion from wastewater samples and solution was reported by Edokpayi et al. [21]. Bassey et al. [22] reported on its use for sequestering some metal ions in solution after modification. In another study, an improvement of water quality using the whitish extract from this plant as a clarifying agent for turbid water was investigated [20]. Surface characteristics and physico-chemical characteristics of the stem biomass concerning heavy metal removal from polluted water were reported by Odiyo and Edokpayi [23]. Apart from the above-mentioned studies, there is a paucity of information on applications of the plant. This study looks into the structural properties and eco-physiological functions of different parts of the studied plant, as well as their contributions during water purification.

\section{Materials and Methods}

The methods described include techniques used for the morphometric and structural characterization, surface characteristics, wettability, and water remediation potentials of the biomass studied.

\subsection{Light Microscopy}

Sectioning for the morphometric study was done using a microtome. Samples were stained with safranin, dehydrated, and studied for morphological and anatomical variations under a light microscope.

\subsection{Structural and Surface Characteristics}

In order to elucidate structural information of the samples, the thermal stability of biomass compositions was studied by thermographimetric analysis and used in calculating the percentage compositions using a TGA 0.5000 with NanoAnalyze Software v3.12.0 (TA Instruments- Waters LLC 109, Lukens Drive, New Castle, DE 19720) under nitrogen. Raman spectra of the samples were acquired with a BRUKER Senterra spectrometer using an OPUS GA gas analysis base package software - Bruker Optics Inc. Billerica, MA USA (excitation lasers wavelengths: $785 \mathrm{~nm}$, laser intensity attenuation: $10 \%$, spectral resolution: 9-18 $\mathrm{cm}^{-1}$; and wavenumber: $90-3750 \mathrm{~cm}^{-1}$ ) in order to observe the intensity and variation in compositions. For surface properties, specific surface $\left(\mathrm{S}_{\mathrm{sp}}\right)$ values and pore size distribution were estimated with nitrogen adsorption, using an ASAP 2020 analyzer (Micrometric Instrument Corporation, USA). The pore volumes and diameters were analyzed using the method of Zemnukhova et al. [24]. Surface imaging of the structures was acquired by scanning electron microscope and processed by SMILE VIEW $^{\mathrm{TM}}$ Map software -JEOL JSM-6010LA, Tokyo, Japan (5-20 kV voltage; 11-12.5 mm work distance). For surface free energy, contact angle measurements of different liquids on sample pellets were measured at $25 \pm 2{ }^{\circ} \mathrm{C}$ using a drop shape instrument FTA 1000 high-performance image (First Ten Angstroms, Newark, New Jersey, United States). Sessile 
drops of $3 \mu \mathrm{l}$ liquids were made on sample pellets using a microsyringe and photographed with a black and white CCD camera [25]. Changes in the contact angle were recorded and averaged. Surface energy, polar, and dispersive components of samples were calculated according to the Owens- Wendt method, based on the Young-Dupre and Fowkes equations. Ultrapure water (milliQ Water system, resistivity $18 \mathrm{X} / \mathrm{cm}$, Millipore), diiodomethane (Acros, 99\%), and glycerol [26] were selected as liquids with desired surface tension properties.

\subsection{Water Purification, Wettability, and Sorption Studies}

The water purification potential of the samples was examined by measuring the adsorptive capacity and methylene blue dye removal potentials of the materials in simulated dye effluent of $10 \mathrm{mg} / \mathrm{L}$ under batch experimental conditions (sorbent: $0.02 \mathrm{~g} / \mathrm{mL}$, agitation: $145 \mathrm{rpm}$, temperature: $25 \pm 2{ }^{\circ} \mathrm{C}$, time: $120 \mathrm{mins}$, and reacting solution: $20 \mathrm{~mL}$ ). The absorbance of treated effluent was monitored at $663 \mathrm{~nm}$ with a UV-Vis spectrophotometer (PG Instrument Ltd., Model T80). Standard dye solutions ranging from 0.5 to $20.0 \mathrm{mg} / \mathrm{L}$ were used to generate analytical calibration furnished by the software of the spectrophotometer $[27,28]$. Subsequently, the concentrations of dye in treated water were calculated automatically from the system software. All analytical measurements were performed in triplicate, and the precision of the standards was higher than $99 \%$ $\left(R^{2}=0.9991\right)$. Wettability and adhesion properties of samples were calculated from surface free energy through drop shape analysis. About 8-10 drop analyses per sample were performed for selected liquids on pressed powdered biomasses. The changes in the contact angles were recorded and averaged. The surface energy, polar, and dispersive components of samples were calculated automatically according to the Owens-Wendt method on a DSA 100 contact angle measuring system equipped with a DSA3 software [25]. Since wettability and adhesion properties of a sample are directly related to the surface free energy [29], these properties can be compared for the various sample using this technique.

\section{Results and Discussion}

\subsection{Morphometric, Structural, and Surface Properties}

The morphometrics of the studied samples are presented in Figure 1. Similarities in structures were observed for biomasses of stem and root, which differs from structures in the leaf. Eco-physiologically, the presence of trichomes in leaf has been associated with sorption [30]. Surface roughness and area properties of the leaf biomass is expected to enhance its sorption behavior. From the results, the fibre length and density are high in root biomass and account for notable variation in the studied samples. Fibres in plants have been associated with eco-physiological functions of water transfer [31] through perforations and pore-like structures. Stem and root with this notable structure may possess enhanced porous nature. There are similarities of structures and metrics in stem and root that differs from those observed in the leaf, which may inform variation in water treatment applications of these samples. 


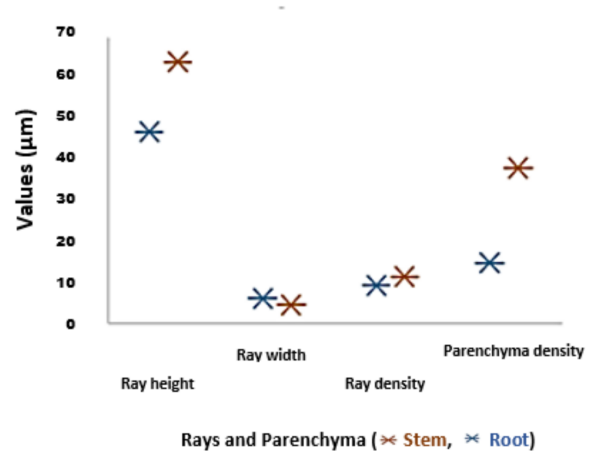

A

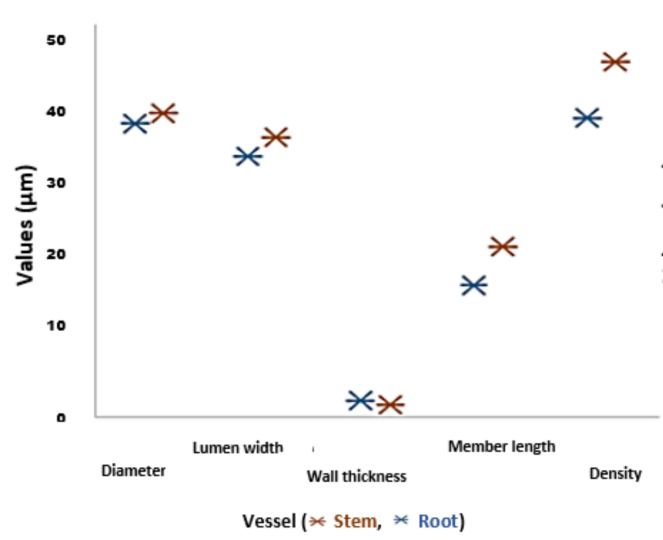

C

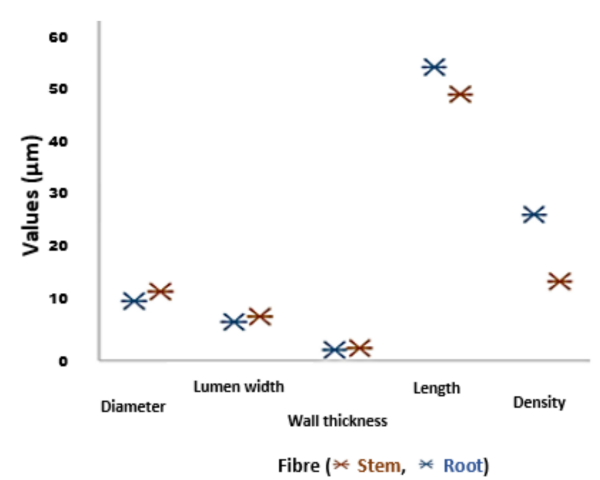

B

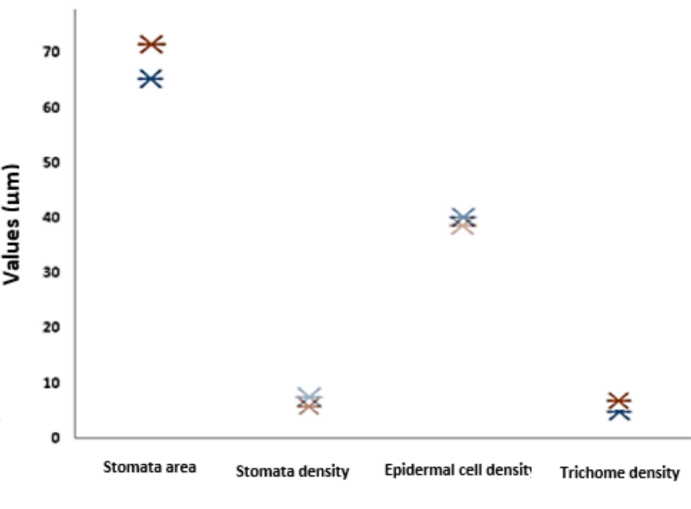

Leaf $(*$ Adaxial, $*$ Abaxial)

D

Figure 1. Morphometric distributions of various cells and tissues in stem and root (A-C) and leaf (D).

Figure 2 shows the profiles of weight loss against temperature for the samples with the characteristic percentage change in biomass over the different temperature range (Figure 2 inset). About $3-5 \%$ of the biomasses account for water and volatile compounds in the parts. This initial loss in weight is due to evaporation and sample dehydration [32]. Around $17-30 \%$ loss in biomass weight is from lignin and combustible mineral residue because of a non-oxidative atmosphere used for thermal analysis [33]. Hemicellulose and cellulose components of the various parts account for $62-78 \%$ mass. These later losses in weight are accounted for by thermal degradation at the elevated temperature used during the thermogravimetric analysis [34]. It is observed that the leaf biomass has the lowest cellulose and hemicellulose content of $62 \%$, while the other biomass portions possessed $70 \%$ or more of cellulose and hemicelluloses composition. Plant biomasses reported in the literature has been reported to consist of $2.47-7.25 \%$ water and extractable soluble substances, about $69 \%$ cellulose, and $14 \%$ lignin $[24,35]$, which is a trend observed during TGA analysis of the studied plant biomasses. 


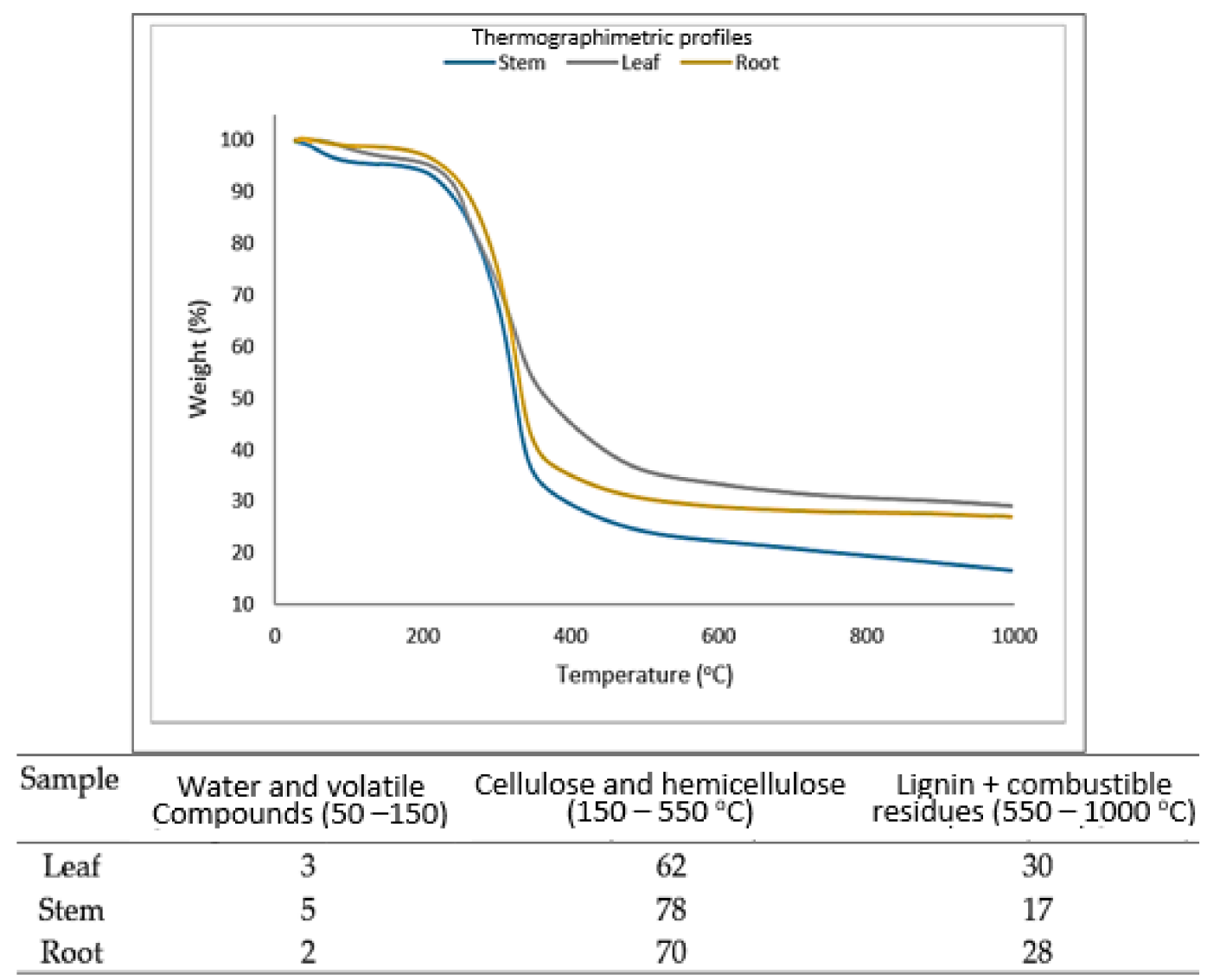

Figure 2. Thermographimetric profiles.

Raman spectroscopic response (Figure 3) establishes higher intensity for root and stem than the content in the leaf portion of the sorbent. It is notable that the trend in total lignin, hemicellulose, and cellulose in TGA for root, stem, and leaf corresponds to the intensity observed in the Raman spectroscopy. The characteristic peaks between the regions of $1500-2000 \mathrm{~cm}^{-1}$ and $2500-3000 \mathrm{~cm}^{-1}$ have been reported for cellulose, lignin, and fibre materials [36].

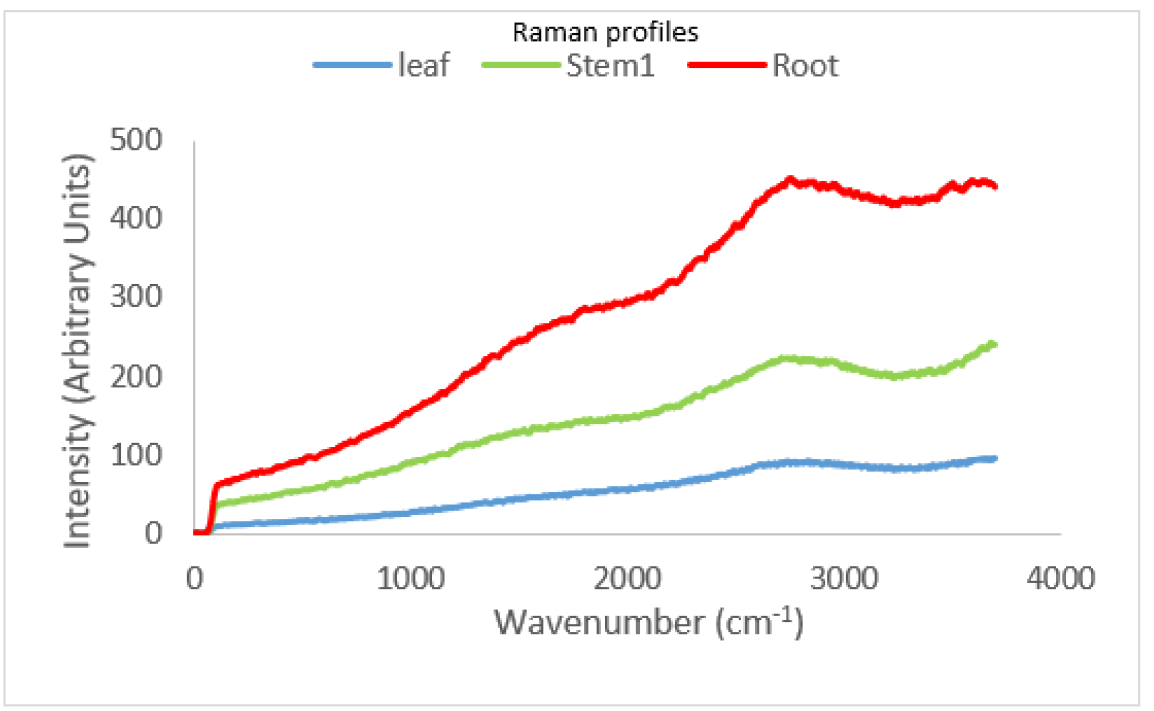

Figure 3. Raman spectroscopy. 
The pore distribution (by Brunaeur-Emmett-Teller (BET)) analyses of the materials are indicated in Table 1, and the surface area properties showed that the leaf biomass exhibited comparatively larger surface area with an average value of $3.34 \mathrm{~m}^{2} / \mathrm{g}$ than the stem and root biomasses. The stem and root are characterized with larger pore sizes, which is suitable for composite material formulation. The large surface area of the leaf is a desired attribute for the sorption of contaminants during water treatment and stabilization of nanomaterials in solution. Biomasses with high surface area have been reported in literature as superior sorbents in solution [37]. As indicated in Figure 4, the materials are mostly microporous. Microporous materials are often used to facilitate the contaminantfree exchange of environmental media where mold spores, bacteria, and other contaminants become trapped and allow for purification of the filtered media. Values reported in this study are similar to those of other authors reporting on surface properties and porosity of plant materials $[38,39]$. The result of SEM (Figure 4) corroborates the observation in the BET and light microscopy studies.

Table 1. Pore size distributions of biomass materials of wild sesame.

\begin{tabular}{cccc}
\hline Parameter & Leaf & Stem & Root \\
\hline $\begin{array}{c}\text { BET surface area } \\
\left(\mathrm{m}^{2} / \mathrm{g}\right)\end{array}$ & 3.340 & 0.300 & 0.270 \\
Pore size $(\mathrm{um})$ & 0.005 & 0.011 & 0.124 \\
\hline
\end{tabular}

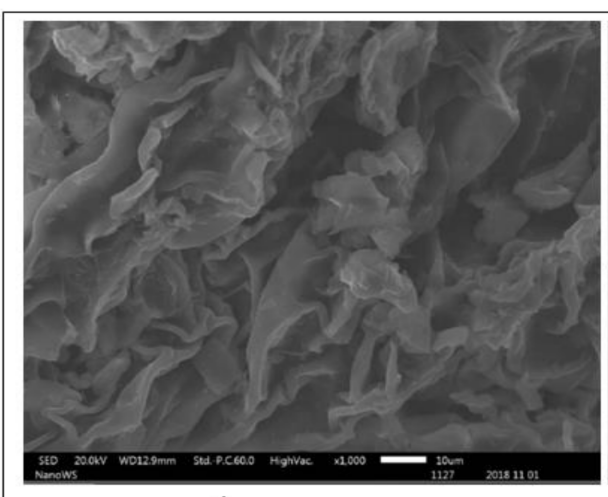

A

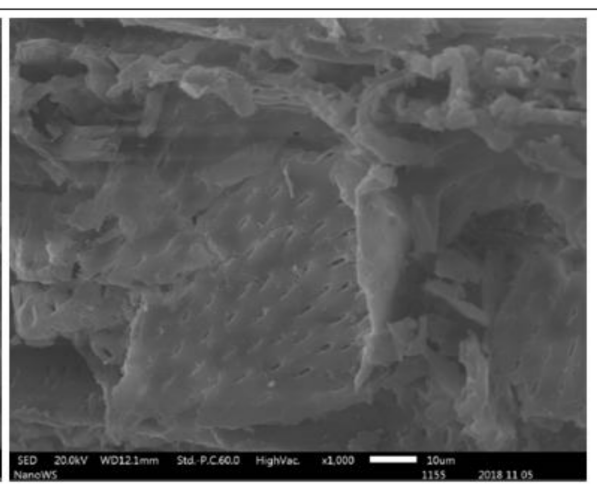

B

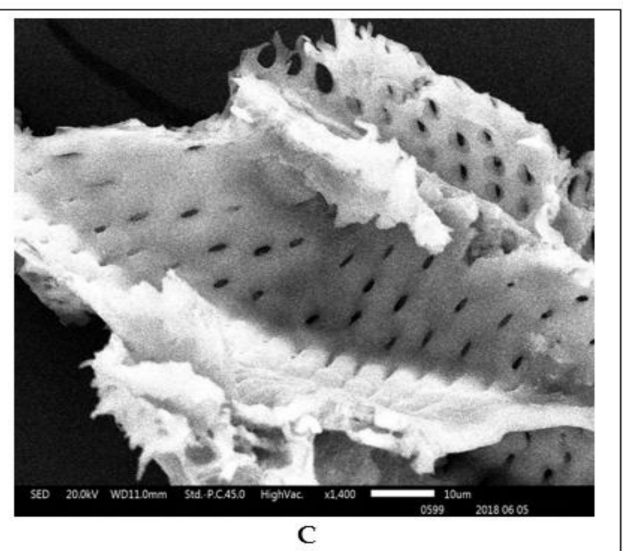

Figure 4. SEM images of plant (A) leaf, (B) stem, and (C) root.

\subsection{Drop Shape Analysis and Sorption Properties}

The liquid drop shape and contact angle properties of the tested materials are indicated in Figure 5 (Inset (D); a sessile dropping sample on pelletized biomass). A similar contact angle response was observed in order of leaf $>$ stem $>$ root except for diiodomethane. Diiodomethane, a non-polar liquid, showed significantly different behaviour with very fast 
liquid absorption. The notable variation in sorption characteristics of the different parts illustrates the compositional variation in the different biomasses of the plant. The leaf does not readily absorb the solvents tested, while the stem and root were easily wetted, which resulted in low contact angle measurement in those samples. As shown in Table 2, the stem and root material possess higher surface energy ( 33.32 and $31.8 \mathrm{mN} / \mathrm{m}$, respectively) than the leaf $(28.03 \mathrm{mN} / \mathrm{m})$ and are higher in dispersive components $(32.45$ and $31.65 \mathrm{mN} / \mathrm{m}$, respectively). The leaf, however, exhibited high polar components $(3.71 \mathrm{mN} / \mathrm{m})$. A positive correlation has been established in the literature for protein content in plant biomass and the polar surface energy component [40], indicating that the leaf biomass consists of high protein constituents, which may be tapped for stabilization of nanomaterials. Surface hydrophobicity has been reported as characteristic of components in plant materials and has been confirmed in the work of Guettler et al. [40]. The high polar nature of the leaf biomass means that its sorbents readily interfere with water treatment processes. The trends of results obtained for water sorption showed that the various parts possessed hydrophilic properties ( $<90^{\circ}$ of contact angle) except for the leaf [41].

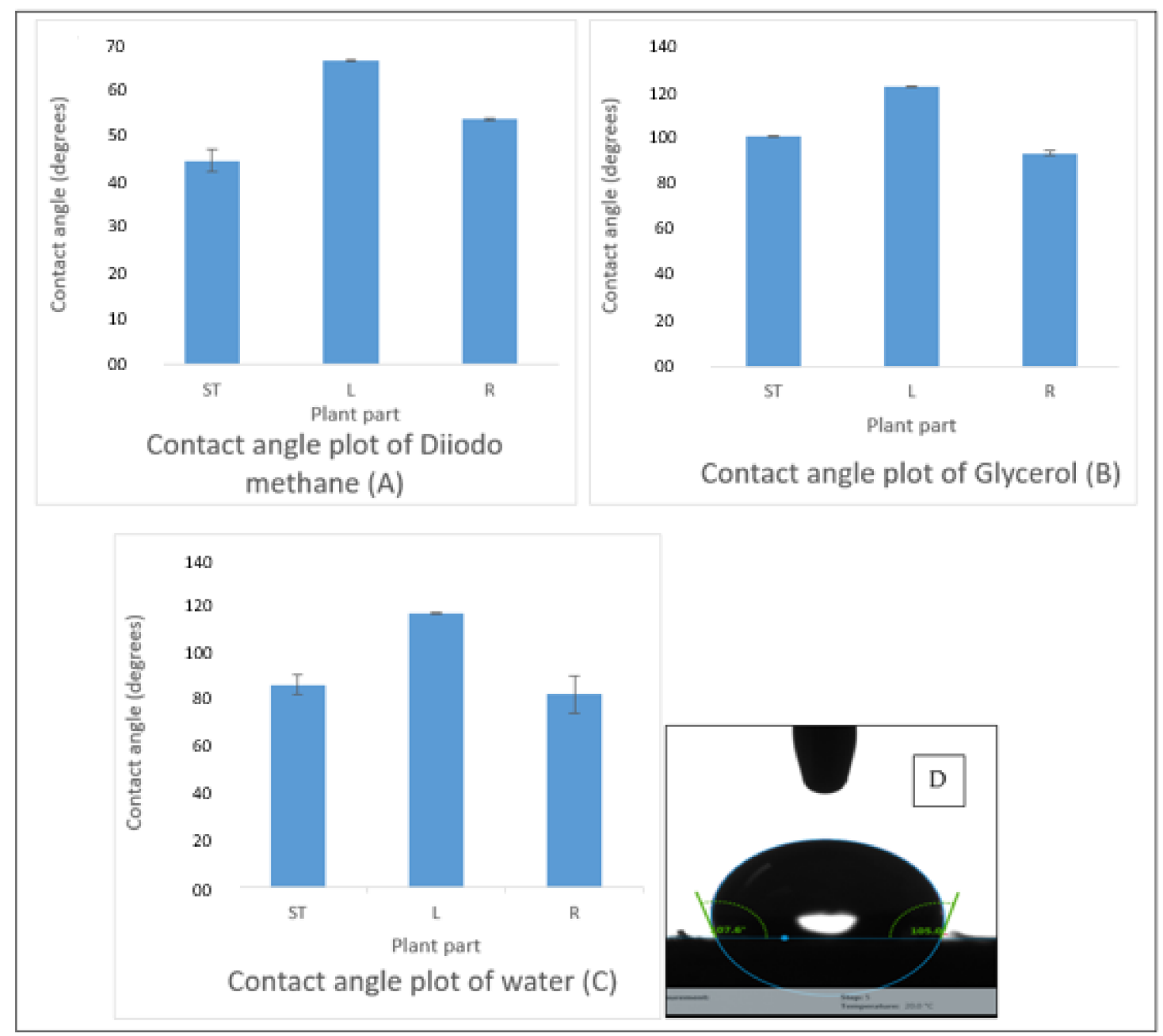

Figure 5. Contact angles of diiodomethane (A), glycerol (B), and water (C) on biomass. NB: (D)—sessile drop on biomass pellet; ST—stem, L = Leaf; R-root. 
Table 2. Surface energy, polar, and dispersive component properties of plant part.

\begin{tabular}{cccc}
\hline Part & Surface Energy $(\mathbf{m N} / \mathbf{m})$ & POLAR $(\mathbf{m N} / \mathbf{m})$ & DISPERSE $(\mathbf{m N} / \mathbf{m})$ \\
\hline Leaf & 27.24 & 3.71 & 23.53 \\
\hline Stem & 33.32 & 0.86 & 32.45 \\
\hline Root & 31.80 & 0.19 & 31.61 \\
\hline
\end{tabular}

Cellulose and hemicellulose constituents or the side groups of amino acids have been reported for a similar trend of wetting and sorption properties in other studies [42,43]. The trends in fibre compositions in relation to the observed sorption characteristic of stem, root, and leaf biomasses confirmed the significant contribution of fibres to sorption. Higher cellulose and hemicellulose contents were in stem and root, which exhibited higher sorption than leaf material. The Microscopy, BET pore size, and TGA analysis support and reflect the superior characteristics of fibre composition of stem and root. Sorbents with low interference during water treatment may, therefore, be targeted from stem and root material, while polar components from leaf may be targeted for stabilization of nanomaterials in solution. Material possessing low polar surface energy and associated low hydrophilicity would be desirable and compatible with hydrophobic polymer materials [40] for composite material development. It has been reported that the chemical characteristics of fibre contribute to variation in contact angle and surface energy [44]. The result for surface energy observed in this study ranged between 27.24 and $33.82 \mathrm{mN} / \mathrm{m}$ for leaf and stem biomasses, respectively. This result falls in the range reported for commercial composite material ( 25.7 and $38.1 \mathrm{mN} / \mathrm{m}$ ), with the dispersive component similarly contributing the main fraction. The stem and root properties best match the surface characteristics of a commercial polymer matrix composite material [41]. With regard to adhesion characteristics, high surface energy is required for optimum decontamination during the water treatment since adhesion properties increase with surface energy properties.

\subsection{Purification of Methylene Blue Dye in Polluted Water}

Simulated dye effluent was used to check the applicability of the sorbents for the treatment of polluted water. The working concentration of the dye was chosen based on the optimum amount reported in the literature [45-47]. More concentrated dye solution may partly dimerize and further polymerize in an aqueous medium, giving rise to apparent deviations from Beer's law. With regard to purification potentials, sorbents prepared from the root and stem materials gave the lowest concentration of dye $0.19 \mathrm{mg} / \mathrm{L}$ and $0.20 \mathrm{mg} / \mathrm{L}$ (which corresponds to 9.81 and $9.80 \mathrm{mg} / \mathrm{L}$ of dye removal, respectively) in treated effluent at 120 mins, which was observed as the equilibrium time. The absorbance and methylene blue dye concentrations after the treatment of the simulated effluent containing $10 \mathrm{mg} / \mathrm{L}$ of dye is presented in Table 3 . While the leaf sorbent resulted in the highest amount of dye in solution $(0.48 \mathrm{mg} / \mathrm{L})$, stem and root resulted in reduced concentrations of 0.20 and $0.19 \mathrm{mg} / \mathrm{L}$, respectively [48]. In the process of dye adsorption, dye molecules initially have to encounter the boundary layer effect and then diffuse from boundary layer film onto an adsorbent surface [49,50]. Finally, they have to diffuse into the porous structure of the adsorbent $[6,48]$. For the leaf biomass, the adsorption process can only be explained by the first two stages since the materials lack the presence of visible pores under a microscope. The stem and root possessed notable pores, and diffusion into the porous structures explains why the biomasses performed better. 
Table 3. Dye sorption properties of treated dye effluent water.

\begin{tabular}{cccc}
\hline Sample & Absorbance & Dye Conc (mg/L) & Sorption (\%) \\
\hline Leaf & 0.0695 & 0.48 & 95.2 \\
\hline Stem & 0.0171 & 0.20 & 98.0 \\
\hline Root & 0.0150 & 0.19 & 98.1 \\
\hline Control & 1.8526 & 10.0 & - \\
\hline
\end{tabular}

The root and stem biomasses have some notable fiber fissures. On the other hand, the leaf appears to have a high surface area which may enhance the amount of absorbed dye [8] Given that the dye molecule may be accommodated in the pores of the adsorbent, sorbents with larger pore sizes are likely to adsorb more molecules of dye in the solution. Implications of porous parameters to adsorption have been described in the literature [51-53]; high specific surface area and pore diameter have been associated with improved efficiency and availability of more adsorption sites during treatment of dye effluents as opposed to a compact structure with low specific surface area and average pore diameters [48]. The surface of a large number of plant-based adsorbents also consists of cellulose fibers, lignins, proteins, and lipids, which offer the necessary functional groups required for the binding of dye molecules. In the report of [15], the fibres of lignocellulosic biomass were employed to remove anionic azo dye (i.e., Congo Red) from an aqueous media. Other structural and surface characteristics such as carbohydrate, surface charge density, topography, and surface area determine biosorption capacity [3]. Adsorption capacity also depends on the adsorptive functional groups on the surface of the adsorbent. The dye molecule diffusion from the media to the surface of the sorbent material occurs in numerous steps [3]. This phenomenon can be governed by one or more processes, such as film or external dispersion, pores diffusion, surface diffusion, pore surface adsorption, or a combination of more than one step during the adsorption process. The pore properties of bio-sorbents [51,52], their structural and textural qualities may aid the sorption of plant biomasses. The surface of fibers with hollow structure in the cellulose of plant was reported for good sorption owing to the presence of hydroxyl functional groups on the biomass material. These textural properties explain the difference in adsorption capacity observed for the various plant sorbents. The result shows that material with better porous properties can be produced from root and stem.

\subsection{Comparative Study Sorption and Functional Studies}

The comparative performance and properties of the seed sorbent with other materials studied are reported in Table 4. Leaf, as a partial storage tissue, possessed lesser pore characteristics comparable to that observed in the seed with similar storage function. High functional and unique sorption characteristics of a polysaccharide extract from the leaf and seed have been reported and widely established for water purification in literature. This is in agreement with the presence of high polar compositions in the leaf and seed biomasses [20-23]. Other reports describe the polyfunctional and water purification properties of similar polysaccharides with a wide band around $1000-1250 \mathrm{~cm}^{-1}$ [54] attributed to $\mathrm{C}-\mathrm{OH}$ stretching of polysaccharide, which disappears after different treatment methods [2]. Eco-physiological functions of water transportation and associated structures may account for improved pores of sorbents prepared from stem and root, which compensates for the lack of functional polysaccharides and polar components. Surface energy compositions of the various parts show that fibres with improved fixtures compensated for enhanced energy of sorption in stem and root with low polysaccharide polymers. The low porous property of seed fibre may account for its differing performance in dye sorption and water purification properties. Baysal et al. [1] already reported the contribution of pith structure in sunflower to availability of close and open pores attributed to the interlaminar spacing, which interestingly retained its structure during carbonization. 
Table 4. Comparative performance of various plant sorbents.

\begin{tabular}{ccccc}
\hline Parts & Seed & Leaf & Stem & Root \\
\hline $\begin{array}{c}\text { Physiological } \\
\text { function }\end{array}$ & Food storage & $\begin{array}{c}\text { Water guttation, } \\
\text { transpiration, and storage }\end{array}$ & $\begin{array}{c}\text { Fluid conduction and } \\
\text { mineral transportation }\end{array}$ & $\begin{array}{c}\text { Water absorption and } \\
\text { transportation }\end{array}$ \\
\hline Surface area $\left(\mathrm{m}^{2} / \mathrm{g}\right)$ & 3.200 & 3.30 & 0.30 & 0.30 \\
\hline Pore size $(\mu \mathrm{m})$ & 0.005 & 0.005 & 0.010 & 0.120 \\
\hline $\begin{array}{c}\text { Surface energy } \\
(\mathrm{mN} / \mathrm{m})\end{array}$ & 28.03 & 27.24 & 33.32 & 31.80 \\
\hline $\begin{array}{c}\text { Polar composition } \\
(\mathrm{mN} / \mathrm{m})\end{array}$ & 3.57 & 3.71 & 0.86 & 0.19 \\
\hline Fibre composition $(\%)$ & 49.0 & 3.0 & 37.0 & 42.0 \\
\hline Dye removal $(\%)$ & 97.4 & 95.2 & 98.0 & 98.1 \\
\hline
\end{tabular}

A similar report by Singh et al. [55] for methylene blue dye sorption in leaves of Ginkgo biloba resulted in $89-91 \%$ dye removal in simulated effluent with a near-equilibrium time of $100 \mathrm{~min}$. Other observations on MB dye removal have been reported on cotton stem, neem leaf powder, and banana leaf powder [56,57]. However, these studies reported removal efficiencies at longer contact times (>120 $\mathrm{min}$ ). At the end of the reaction, plant biomasses became saturated, suggesting maximum engagement of functional groups available in the various samples for dye removal. The samples' coloration changed from somewhat brownish to blue.

\section{Conclusions}

This study has established relationships between eco-physiological properties and the sorption behavior of plant sorbents used for water purification. Surface properties, fibre compositions, and porous characteristics of the plant biomasses are important when considering plant sorbent for water purification. Establishing the polar and dispersive components of each part has informed the probable water treatment application path for each of the plant parts studied. Phytochemical signatures and functional properties of the wild sesame studied need to be assessed for its further exploration in phyto-biotechnology.

Author Contributions: A.O.A. and J.O.O. conceptualized the study; resources mobilization and data curation were done by H.D.M., T.A.M.M. and M.M.M.; writing of original draft and preparation, A.O.A.; writing-review and editing, A.O.A.; J.O.O., and R.M.; supervision, J.O.O. and A.M.E.; funding acquisition, J.O.O. and A.M.E. All authors have read and agreed to the published version of the manuscript and authorship has been limited to those who have contributed substantially to the work reported.

Funding: This research was funded by the University of Venda Research and Publication Grant, Grant Number G094, and the Water Research Commission Grant, Project number K5/2808.

Institutional Review Board Statement: Not applicable.

Informed Consent Statement: Not applicable.

Acknowledgments: AOA acknowledges the contributions of Guegium-Kana EGB, Lateef A and J.O Odiyo for their rigorous training support at his foundational level.

Conflicts of Interest: The authors declare no conflict of interest. The funders had no role in the design of the study; in the collection, analyses, or interpretation of data; in the writing of the manuscript, or in the decision to publish the results.

\section{References}

1. Baysal, M.; Bilge, K.; Yılmaz, B.; Papila, M.; Yürüm, Y. Preparation of high surface area activated carbon from waste-biomass of sunflower piths: Kinetics and equilibrium studies on the dye removal. J. Environ. Chem. Eng. 2018, 6, 1702-1713. [CrossRef] 
2. Taleb, F.; Ammar, M.; Mosbah, M.B.; Salem, R.B.; Moussaoui, Y. Chemical modification of lignin derived from spent coffee grounds for methylene blue adsorption. Sci. Rep. 2020, 10, 11048. [CrossRef]

3. Bayramoglu, G.; Adiguzel, N.; Ersoy, G.; Yilmaz, M.; Arica, M.Y. Removal of Textile Dyes from Aqueous Solution using Amine-Modified Plant Biomass of A. caricum: Equilibrium and Kinetic Studies. Water Air Soil Pollut. 2013, 224, 1640. [CrossRef]

4. Mohan, D.; Singh, K.P.; Sinha, S.; Gosh, D. Removal of pyridine from aqueous solution using low cost activated carbons derived from agricultural waste materials. Carbon 2004, 42, 2409-2421. [CrossRef]

5. Bayramoglu, G.; Celik, G.; Arica, M.Y. Biosorption of Reactive Blue 4 dye by native and treated fungus Phanerocheate chrysosporium: Batch and continuous flow system studies. J. Hazard. Mater. 2006, 137, 1689-1697. [CrossRef] [PubMed]

6. Bayramoglu, G.; Arica, M.Y. Preparation of a composite biosorbent using Scenedesmus quadricauda biomass and alginate/polyvinyl alcohol for removal of $\mathrm{Cu}(\mathrm{II})$ and $\mathrm{Cd}(\mathrm{II})$ ions: Isotherms, kinetics, and thermodynamic studies. Water Air Soil Pollut. 2011, 221, 391-403. [CrossRef]

7. Trevisan, C.W.; Foletto, E.L.; Meili, L. Removal of tannery dye from aqueous solution using papaya seed as an efficient natural biosorbent. Water Air Soil Pollut. 2013, 224, 1427.

8. Cardoso, N.F.; Pinto, R.B.; Lima, E.C.; Calvete, T.; Amavisca, C.V.; Royer, B.; Cunha, M.L.; Fernandes, T.H.M.; Pinto, I.S. Removal of remazol black B textile dye from aqueous solution by adsorption. Desalination 2011, 269, 92-103. [CrossRef]

9. Tan, I.A.W.; Ahmad, A.L.; Hameed, B.H. Adsorption of basic dye on high-surface-area activated carbon prepared from coconut husk: Equilibrium, kinetic and thermodynamic studies. J. Hazard. Mater. 2008, 154, 337-346. [CrossRef]

10. Dias, J.M.; Alvim-Ferraz, M.C.M.; Almeida, M.F.; Rivera-Utrilla, J.; Sánchez-Polo, M. Waste materials for activated carbon preparation and its use in aqueous-phase treatment: A review. J. Environ. Manag. 2007, 85, 833-846. [CrossRef]

11. Akar, T.; Ozcan, A.S.; Tunali, S.; Ozcan, A. Biosorption of a textile dye (Acid Blue 40) by cone biomass of Thuja orientalis: Estimation of equilibrium, thermodynamic and kinetic parameters. Bioresour. Technol. 2008, 99, 3057-3065. [CrossRef]

12. Krishnan, K.; Meng, X.; Christodoulatos, C.; Boddu, V.M. Biosorption mechanism of nine different heavy metals onto biomatrix from rice husk. J. Hazard. Mater. 2008, 153, 1222-1234. [CrossRef]

13. Safa, Y.; Bhatti, H.N. Kinetic and thermodynamic modeling for the removal of Direct Red-31 and Direct Orange-26 dyes from aqueous solutions by rice husk. Desalination 2011, 272, 313-322. [CrossRef]

14. Gercel, O.; Gercel, H.F.; Koparal, A.S.; Ogutveren, U.B. Removal of disperse dye from aqueous solution by novel adsorbent prepared from biomass plant material biomass of Thuja orientalis. J. Hazard. Mater. 2008, 160, 668-674. [CrossRef]

15. Roy, A.; Chakraborty, S.; Kundu, S.P.; Adhikari, B.; Majumder, S.B. Adsorption of anionic-azo dye from aqueous solution by lignocellulose-biomass jute fiber: Equilibrium, kinetics, and thermodynamics study. Ind. Eng. Chem. Res. 2012, 51, 12095-12106. [CrossRef]

16. Prasad, M.N.V.; Freitas, H. Removal of toxic metals from solution by leaf, stem and root phytomass of Quercus ilex L. Environ. Pollut. 2000, 110, 277-283. [CrossRef]

17. Luseba, D.; Elgorashe, E.E.; Ntloedibe, D.T.; van-Staden, J. Antibacterial, anti-inflammatory and mutagenic effects of some medicinal plants used in South Africa for the treatment of wounds and retained placenta in livestock. S. Afr. J. Bot. 2007, 73, 378-383. [CrossRef]

18. Madiga, M.C.; Cockeran, R.; Mokgotho, M.P.; Anderson, R.; Mampuru, L.J. Dichloromethane extract of Dicerocaryum senecioides leaves exhibits remarkable anti-inflammatory activity in human T-lymphocytes. Nat. Prod. Res. 2009, 23, 998-1006. [CrossRef] [PubMed]

19. More, G.K.; Tshikalange, T.E.; Lall, N.; Meyer, J.J.M.; Botha, F.S.; Hussein, A.A. Antimicrobial activity of medicinal plants against oral microorganisms. S. Afri. J.Bot. 2007, 73, 332. [CrossRef]

20. Odiyo, J.; Bassey, O.; Ochieng, A.; Chimuka, L. Coagulation efficiency of Dicerocaryum eriocarpum (DE) plant. Water SA 2017, 43, 1-6. [CrossRef]

21. Edokpayi, J.N.; Odiyo, J.O.; Msagati, T.A.M.; Popoola, E.O. Removal Efficiency of Faecal Indicator Organisms, Nutrients and Heavy Metals from a Peri-Urban Wastewater Treatment Plant in Thohoyandou, Limpopo Province, South Africa. Int. J. Environ. Res. Public Health 2015, 12, 7300-7320. [CrossRef]

22. Bassey, O.J.; Odiyo, J.O.; Chimuka, L.; Aoyi, O.; Bridget, J.B. Application of mucilage from Dicerocaryum eriocarpum plant as biosorption medium in the removal of selected heavy metal ions. J. Environ. Manag. 2016, 177, 365-372.

23. Odiyo, J.O.; Edokpayi, J.N. Physico-chemical and surface characterisation of a renewable low-cost biosorbent for the uptake of heavy metal ions from aqueous solution. WIT Trans. Ecol. Environ. 2018, 228, 317-327.

24. Zemnukhova, L.A.; Panasenko, A.E.; Artem'yanov, A.P.; Tsoy, E.A. Dependence of porosity of amorphous silicon dioxide prepared from rice straw on plant variety.Silicon dioxide rice straw. BioResources 2015, 10, 3713-3723. [CrossRef]

25. Krüss GmbH. DSA1 v 1.9 Drop Shape Analysis for DSA100. 2004. Available online: https://warwick.ac.uk/fac/cross_fac/ sciencecity/programmes/internal/themes/am2/booking/dropshapeanalyser/kruss_manual-dsa100.pdf (accessed on 1 July 2021).

26. Aranberri-Askargorta, I.; Lampke, T.; Bismarck, A. Wetting behavior of flax fibers as reinforcement for polypropylene. J. Colloid. Interface Sci. 2003, 263, 580-589. [CrossRef] [PubMed]

27. Vaghetti, J.C.P.; Lima, E.C.; Royer, B.; Brasil, J.L.; da Cunha, B.M.; Simon, N.M.; Cardoso, N.F.; Noreña, C.P.Z. Application of Brazilian-pine fruit coat as a biosorbent to removal of $\mathrm{Cr}(\mathrm{VI})$ from aqueous solution. Kinetics and equilibrium study. Biochem. Eng. J. 2008, 42, 67-76. [CrossRef] 
28. Adeeyo, A.O.; Odiyo, J.O. Biogenic Synthesis of Silver Nanoparticle From Mushroom Exopolysaccharides and Its Potentials in Water Purification. Open Chem. J. 2018, 5, 64-75. [CrossRef]

29. Song, K.; Lee, J.; Choi, S.-O.; Kim, J. Interaction of Surface Energy Components between Solid and Liquid on Wettability, and Its Application to Textile Anti-Wetting Finish. Polymers 2019, 11, 498. [CrossRef] [PubMed]

30. Versieux, L.M.; Medeiros, A.S.M. Leaf anatomical characterization of Guzmania Ruiz \& Pav. and Mezobromelia L.B.Sm. (Tillandsioideae, Bromeliaceae). J. Bromel. Soc. 2018, 67, 2018.

31. Rungsung, W.; Dutta, S.; Mondal, D.N.; Ratha, K.K.; Hazra, J. Pharmacognostical Profiling on the Root of Rauwolfia Serpentina. Int. J. Pharmacogn. Phytochem. Res. 2014, 6, 612-616.

32. Edokpayi, J.N.; Ndlovu, S.S.; Odiyo, J.O. Characterization of pulverized Marula seed husk and its potential for the sequestration of methylene blue from aqueous solution. BMC Chem. 2019, 13, 10. [CrossRef]

33. Malucellia, L.; Massulob, T.; Magalhãesc, W.; Stofella, N.; Vasconcelosa, E.; Filho, M.; Murakamid, F. Thermal and chemical characterization of Dicksonia sellowiana extract by means of thermal analysis. Rev. Bras. Farmacogn. 2018, 28, 626-630. [CrossRef]

34. Postai, D.L.; Demarchi, C.A.; Zanatta, F. Adsorption of rhodamine B and methylene blue dyes using waste of seeds of Aleurites Moluccana, a low-cost adsorbent. Alex. Eng. J. 2016, 55, 1713-1723. [CrossRef]

35. Ghasemi, E.; Ghorbani, G.R.; Khorvash, M.; Emam, M.R.; Karimi, K. Chemical composition, cell wall features and degradability of stem, leaf blade and sheath in untreated and alkali-treated rice straw. Animal 2013, 7, 1106-1112. [CrossRef]

36. Schulz, H.; Baranska, M. Identification and quantification of valuable plant substances by IR and Raman spectroscopy. Vib. Spectrosc. 2007, 43, 13-25. [CrossRef]

37. Elizalde-Gonzalez, M.P.; Mattusch, J.; Pelaez-Cid, A.A.; Wennrich, R. Characterization of adsorbent materials prepared from avocado kernel seeds: Natural, activated and carbonized forms. J. Anal. Appl. Pyrolysis 2007, 78, 185-193. [CrossRef]

38. Zvinowanda, C.M.; Okonkwo, J.O.; Agyei, N.M.; Shabalala, P.N. Physicochemical characterization of maize tassel as an adsorbent. I. surface texture, microstructure and thermal stability. J. Appl. Polym. Sci. 2009, 111, 1923-1930. [CrossRef]

39. Rodrigues, L.A.; Ribeiro, L.A.D.; Thim, G.P.; Ferreira, R.R.; Alvarez-Mendez, M.O.; Coutinho, A.D. Activated carbon derived from macadamia nut shells: An effective adsorbent for phenol removal. J. Porous Mater. 2013, 20, 619-627. [CrossRef]

40. Guettler, B.E.; Moresoli, C.; Simon, L.C. Contact angle and surface energy analysis of soy materials subjected to potassium permanganate and autoclave treatment. Ind. Crops Prod. 2013, 50, 219-226. [CrossRef]

41. Diversified Enterprises. Surface Energy Data for PP: Polypropylene, CAS \#s9003-08-0 (Atactic) and 25085-53-4 (Isotactic). 2009, p. 3. Available online: http:/ / www.accudynetest.com/polymer_surface_data/polypropylene.pdf (accessed on 1 July 2021).

42. Paul, A.; Joseph, K.; Thomas, S. Effect of surface treatments on the electrical properties of low-density polyethylene composites reinforcedwith short sisal fibers. Compos. Sci. Technol. 1997, 57, 67-79. [CrossRef]

43. Shaabani, A.; Lee, D. Solvent free permanganate oxidations. Tetrahedron Lett. 2001, 42, 5833-5836. [CrossRef]

44. Alix, S.; Philippe, E.; Bessadok, A.; Lebrun, L.; Morvan, C.; Marais, S. Effect of chemical treatments on water sorption and mechanical properties of flax fibres. Bioresour. Technol. 2009, 100, 4742-4749. [CrossRef] [PubMed]

45. Ozdemir, F.A.; Demirata, B.; Apak, R. Adsorptive removal of methylene blue from simulated dyeing wastewater with melamineformaldehyde-urea resin. J. Appl. Polym. Sci. 2009, 112, 3442-3448. [CrossRef]

46. Guo, C.; Kong, Q.; Gao, J.; Ji, Q.; Xia, Y. Removal Of methylene blue dye from simulated wastewater by alginic acid fiber as adsorbent: Equilibrium, kinetic, and thermodynamic studies. Can. J. Chem. Eng. 2011, 89, 1545-1553. [CrossRef]

47. Anisuzzaman, S.M.; Joseph, C.G.; Krishnaiah, D.; Bono, A.; Ooi, L.C. Parametric and adsorption kinetic studies of methylene blue removal from simulated textile water using durian (Durio zibethinus murray) skin. Water Sci. Technol. 2015, 72, 896-907. [CrossRef]

48. Garg, V.K.; Kumar, R.; Gupta, R. Removal of malachite green dye from aqueous solution by adsorption using agro-industry waste: A case study of Prosopis cineraria. Dyes Pigments 2004, 62, 1-10. [CrossRef]

49. Vaghetti, J.C.P.; Lima, E.C.; Royer, B.; da Cunha, B.M.; Cardoso, N.F.; Brasil, J.L.; Dias, S.L.P. Pecan nutshell as biosorbent to remove $\mathrm{Cu}(\mathrm{II}), \mathrm{Mn}(\mathrm{II})$ and $\mathrm{Pb}(\mathrm{II})$ from aqueous solutions. J. Hazard. Mater. 2009, 162, 270-280. [CrossRef]

50. Vaghetti, J.C.P.; Lima, E.C.; Royer, B.; Cardoso, N.F.; Martins, B.; Calvete, T. Pecan nutshell as biosorbent to remove toxic metals from aqueous solution. Sep. Sci. Technol. 2009, 44, 615-644. [CrossRef]

51. Calvete, T.; Lima, E.C.; Cardoso, N.F.; Dias, S.L.P.; Pavan, F.A. Application of carbon adsorbents prepared from the Brazilian-pine fruit shell for removal of Procion Red MX 3B from aqueous solution-kinetic, equilibrium, and thermodynamic studies. Chem. Eng. J. 2009, 155, 627-636. [CrossRef]

52. Royer, B.; Cardoso, N.F.; Lima, E.C.; Vaghetti, J.C.P.; Simon, N.M.; Calvete, T.; Veses, R.C. Applications of Brazilian-pine fruit shell in natural and carbonized forms as adsorbents to removal of methylene blue from aqueous solutions-kinetic and equilibrium study. J. Hazard. Mater. 2009, 164, 1213-1222. [CrossRef]

53. Calvete, T.; Lima, E.C.; Cardoso, N.F.; Vaghetti, J.C.P.; Dias, S.L.P.; Pavan, F.A. Application of carbon adsorbents prepared from Brazilian-pine fruit shell for the removal of reactive orange 16 from aqueous solution: Kinetic, equilibrium, and thermodynamic studies. J. Environ. Manag. 2010, 91, 1695-1706. [CrossRef]

54. Hassan, W.; Farooq, U.; Ahmad, M.; Athar, M.; Khan, M.A. Potential biosorbent, Haloxylon recurvum plant stems, for the removal of methylene blue dye. Arab. J. Chem. 2017, 10, S1512-S1522. [CrossRef]

55. Singh, R.; Singh, T.S.; Odiyo, J.O.; Smith, J.A.; Edokpayi, J.N. Evaluation of Methylene Blue Sorption onto Low-Cost Biosorbents: Equilibrium, Kinetics, and Thermodynamics. J. Chem. 2020, 2020, 8318049. [CrossRef] 
56. Deng, H.; Lu, J.; Li, G.; Zhang, G.; Wang, X. Adsorption of methylene blue on adsorbent materials produced from cotton stalk. Chem. Eng. J. 2011, 172, 326-334. [CrossRef]

57. Krishni, R.R.; Foo, K.Y.; Hameed, B.H. Adsorptive removal of methylene blue using the natural adsorbent-banana leaves. Desalin. Water Treat. 2014, 52, 6104. [CrossRef] 